\title{
PHARMACOLOGICAL EVALUATION OF THE ANTINOCICEPTIVE AND ANTI- INFLAMMATORY ACTIVITY OF THE SPECIES ENDOPLEURA UCHI
}

\author{
Matheus Kleber de Jesus Souza ${ }^{1}$, Gutemberg Lopes Soares ${ }^{2}$, Fernanda Guilhon- \\ Simplicio ${ }^{3}$, Andrea de Castro Perez ${ }^{4}$, Clarice de Carvalho Veloso Moura ${ }^{5}$ \\ ${ }^{1}$ Graduando em Farmácia pela Universidade Federal do Amazonas, Manaus-AM \\ ${ }^{2}$ Mestre em Ciências Farmacêuticas pela Universidade Federal do Amazonas, \\ Manaus-AM \\ ${ }^{3}$ Professora Adjunto da Faculdade de Ciências Farmacêuticas pela Universidade \\ Federal do Amazonas, Manaus-AM \\ ${ }^{4}$ Professora Associado do Instituto de Ciências Biológicas pela Universidade Federal \\ de Minas Gerais, Belo Horizonte-MG \\ ${ }^{3}$ Professora Adjunto da Faculdade de Ciências Farmacêuticas pela Universidade \\ Federal do Amazonas, Manaus-AM. E-mail: claricecv@gmail.com
}

\author{
Recebido em: 15/11/2021 - Aprovado em: 15/12/2021 - Publicado em: 30/12/2021 \\ DOI: 10.18677/EnciBio 2021D39 \\ trabalho licenciado sob licença Creative Commons Attribution-NonCommercial-NoDerivatives 4.0 International License.
}

\begin{abstract}
The use of plants for medicinal purposes for the treatment, cure and prevention of diseases is one of the oldest forms of medicinal practice in humanity, where the Amazon region has a huge variety of plant species, which are used for medicinal purposes. An example is Endopleura uchi, popularly known as "yellow uchi", used in the form of tea made from the bark, as it performs anti-inflammatory and antioxidant actions, among others. Based on popular knowledge about the medicinal use of the species, this study aimed to evaluate the anti-inflammatory and antinociceptive activities and perform the phytochemical screening of the hydroethanolic extract of the bark of the species Endopleura uchi (HEEu). In the phytochemical screening, both the hydroethanolic extract and the raw material were used and the presence of phenolic compounds, tannins and saponins can be found. To evaluate the antiinflammatory activity, the method of paw edema induced by carrageenan was used, and to evaluate the antinociceptive activity, the test of abdominal writhing induced by acetic acid was used. The rota-rod test was used to assess whether the extract interferes with the animals' motor coordination. Thus, the presence of secondary metabolites was detected and anti-inflammatory and antinociceptive activity demonstrated.
\end{abstract}

KEYWORDS: Ethnopharmacology; Inflammation; Inflammatory pain 


\section{AVALIAÇÃO FARMACOLÓGICA DA ATIVIDADE ANTINOCICEPTIVA E ANTI- INFLAMATÓRIA DA ESPÉCIE ENDOPLEURA UCHI}

\section{RESUMO}

O uso de plantas para fins medicinais para o tratamento, cura e prevenção de doenças é uma das mais antigas formas de prática medicinal da humanidade, onde a região amazônica possui uma grande variedade de espécies vegetais, que são utilizadas para fins medicinais. Um exemplo é a Endopleura uchi, popularmente conhecida como "uchi amarelo", utilizado na forma de chá feito a partir da casca, pois exerce ações antiinflamatórias e antioxidantes, entre outras. Com base no conhecimento popular sobre o uso medicinal da espécie, este trabalho teve como objetivo avaliar as atividades antiinflamatória e antinociceptiva e realizar a triagem fitoquímica do extrato hidroetanólico da casca da espécie Endopleura uchi (HEEu). $\mathrm{Na}$ triagem fitoquímica, foram utilizados tanto o extrato hidroetanólico quanto a matéria-prima e constatou-se a presença de compostos fenólicos, taninos e saponinas. Para avaliar a atividade antiinflamatória, foi utilizado o método do edema de pata induzido por carragenina e, para avaliar a atividade antinociceptiva, foi utilizado o teste de contorções abdominais induzidas por ácido acético. O teste do rota-rod foi utilizado para avaliar se o extrato interfere na coordenação motora dos animais. Assim, foi detectada a presença de metabólitos secundários e demonstrada a atividade antiinflamatória e antinociceptiva.

PALAVRAS-CHAVE: Dor Inflamatória. Etnofarmacologia; Inflamação;

\section{INTRODUCTION}

The use of plants for medicinal purposes, for the treatment, cure and prevention of diseases, is one of the oldest forms of medicinal practice in humanity. From this use, several questions arose, like the one asking if they were being used for therapeutic purposes because of this studies were carried out to prove the biological activity of the species and thus have proven efficacy (BRASIL, 2006; TOMAZZONI et al., 2008; BADKE et al., 2016).

In this context, the Amazon region constitutes the largest tropical forest ecosystem in the world, with an enormous flora that has countless uses, ranging from food to the treatment of diseases (AMOROZO; GELY, 1988; FISCHMAN et al., 1991; AKERELE, 1993; VEIGA JUNIOR et al., 2005).

A species of this enormous flora that can be found in the Amazon region is Endopleura uchi, popularly known as "yellow uchi", belonging to the genus Endopleura. It is found in terra firme forest and used in the form of tea made from the bark of the tree, which has popular use for the treatment of various pathologies, such as arthritis, and anti-inflammatory, antimutagenic, antioxidant, antitumor, antiviral, cytostatic actions, depurative, diuretic, hypotensive, immunostimulant, cell regenerator and vermifuge (CUATRECASA, 1961; SABATIER, 2004; BORGES, 2010, OLIVEIRA et al. 2017).

Previous studies demonstrated that the $E$. uchi species had the presence of secondary metabolites, found in the bark. Among the main classes of molecules are tannins, coumarins and saponins (FREITAS et al., 2018). From the method of high performance liquid chromatography (HPLC) coupled with diode array detection (DAD) phenolic compounds were detected, including bergenine and its derivatives 
(SILVA; TEIXEIRA, 2015). Abreu et al. (2008), indicated in their work that bergenin is the molecule responsible for the biological activity of this species.

Other studies evaluated the activity of different extracts obtained from Endopleura uchi bark and observed lipase inhibitory, antioxidant, antimicrobial, antidiabetic and anti-inflammatory action (SILVA et al., 2009; NUNOMURA et al., 2009; POLITI et al., 2009; POLITI et al., 2009; SILVA; TEIXEIRA, 2015; OLIVEIRA et al., 2017).

Therefore, considering the popular use of the species Endopleura uchi for the treatment of painful inflammatory diseases, the aim of the present study was to evaluate the pharmacological potential of the hydroethanolic extract obtained from the barks of this species in animal models of nociception and inflammation, in addition to evaluating the in vitro antioxidant activity and phytochemical prospecting, thus contributing to obtain data that demonstrate the pharmacological efficacy from information on popular medicinal use.

Plant

\section{MATERIAL AND METHODS}

Barks of the Endopleura uchi species were used, purchased at "Produtos Naturais Dr. Juan Revilla" store. The plant exsiccate was collected in May 1996, by the botanist D.F. Coelho and deposited in the herbarium of the Federal University of Amazonas, under number 4359.

\section{Hydroethanolic extract}

The preparation of the hydroethanolic extract of the bark of the Endopleura uchi species (HEEu) was carried out from 150 grams of sample in which $70 \%$ ethanol was added. Leaving it for 48 hours, after this period, vacuum filtration was necessary. Then, the solvent evaporation step took place in a rotaevaporator. The solution obtained after the evaporation process was lyophilized, giving rise to a powdery residue (hydroethanolic extract).

\section{Animals}

Male mice of the species Balb/c (20-30 g), provided by the Central Animal Facility of the Amazon Research Institute (INPA), were used in the in vivo tests, following all the norms and ethics related to this type of research. They were placed in cages and kept in an environment with a temperature between $23 \pm 2{ }^{\circ} \mathrm{C}, 12 \mathrm{~h}$ light/dark cycle and with free access to drinking water and feed. Except on the day of the experiment when the feed was withdrawn and the animals were fasted for a period of 5 hours. The project was approved by the Committee on Ethics and Research in the Use of Animals of the National Institute for Research in the Amazon (INPA), under protocol number 042/2016.

\section{Phytochemical Prospecting}

This essay analyzes all the qualitative characteristics of the main chemical groups that constitute the active principles of plant drugs, using in each case, color and/or precipitation reactions. For this test, HEEu and the vegetal raw material of the species Endopleura uchi were used. The tests to carry out the phytochemical prospecting are in accordance with the methodologies described by Costa (2002) and Simões (2010). 


\section{Paw edema induced by intraplantar carrageenan injection}

This test was based on a similar methodology described by Levy (1969). The paw edema was assessed using an electrical hydroplestymometer (Panlab, SLU). This device measures the displaced liquid volume and translates it digitally. The basal volume of the right hind paw was determined before the administration of any drug. The mice were divided into experimental groups. Vehicle $(5 \%$ solution of $70 \%$ alcohol in saline solution; $10 \mathrm{~mL} / \mathrm{kg}$ ), HEEu (100 and $300.0 \mathrm{mg} / \mathrm{kg}$ ) and indomethacin (10 mg/kg) were administered orally 1 hour before intraplantar injection (i .pl.) of carrageenan $(300.0 \mu \mathrm{g}, 30.0 \mu \mathrm{l})$. Each group consisted of 4 to 6 mice. The choice of carrageenan concentration and injected volume was based on the dose-response curve obtained in a previous study carried out by Veloso (2014). The paw volume was measured $1.0 ; 2.0 ; 3.0$ and 4.0 hours after injection of the inflammatory stimulus. The results were presented as the variation of the volume of the paw ( I) in relation to the basal value.

\section{Acetic acid-induced abdominal writhing test}

This test was based on a methodology previously described by Koster et al. (1959), where the intensity of nociceptive behavior was quantified by counting the total number of contortions that occurred between 0 and 20 minutes after stimulus injection. Acetic acid $(0.9 \% \mathrm{v} / \mathrm{v}, 10 \mathrm{~mL} / \mathrm{kg})$ was injected into the peritoneal cavity of mice 1 hour after receiving the pre-treatment according to each experimental group. Group 1 received only the vehicle (5\% solution of $70 \%$ alcohol in saline solution; 10 $\mathrm{mL} / \mathrm{kg}$ ). Group 2 received indomethacin at a dose of $10 \mathrm{mg} / \mathrm{kg}$. Groups 3 and 4 received orally, HEEu at doses of 100 and $300 \mathrm{mg} / \mathrm{kg}$, respectively. Each group consisted of $4-6$ mice. Then, they were placed in a large plastic cylinder, and the intensity of the nociceptive behavior was quantified by counting the total number of contortions. The contortion response consists of contraction of the abdominal muscle with stretching of the hind limbs. Antinociceptive activity was expressed as a score of writhing in a 20-minute period.

\section{Motor coordination test}

The motor coordination was assessed by the time the animal remained walking on the rota-rod for 2 minutes (cutting time), according to the methodology described by Dunham and Miya (1957) with alterations. Rota-rod is a horizontal revolving bar, coated with non-slip plastic, suspended at a height of 25 to $30 \mathrm{~cm}$ and with a constant rotation of $16 \mathrm{rpm}$.

\section{RESULTS AND DISCUSSION}

Endopleura uchi is used in the form of a tea made from the bark of the tree, which is popularly used to treat arthritis, inflammation, diuretic and cytostatic actions, among others (CUATRECASA, 1961; BORGES, 2010). This is a study which sought to elucidate the anti-inflammatory and antinociceptive action of the hydroethanolic extract of Endopleura uchi bark in animal models. In addition, the phytochemical prospection of HEEu was carried out. The results showed: I) the phytochemical prospection assay was used for the analysis of both the Endopleura uchi and HEEu bark species, so from the prospecting it was demonstrated that both had phenolic compounds, tannins and saponins. However, in HEEu, in addition to the afore 
mentioned secondary metabolites, anthocyanins, anthocyanidins and leucoanthocyanidins were also present; II) in the in vivo analysis, the oral administration of HEEu produced antinociceptive and anti-inflammatory effects and did not produce any change in the motor performance in vivo.

The phytochemical screening performed with the bark of the Endopleura uchi species and its hydroethanolic extract (HEEu) was carried out from the characterization of the main chemical groups of plant substances through characteristic precipitation and coloring reactions, as shown in Table 1.

TABLE 1: Phytochemical screening of the raw material (shells) and the hydroethanolic extract of the barks of the species Endoplera uchi (EHEu).

\section{Secondary metabolites $\quad$ Characterization reaction Raw HEEu} material

Phenolic compounds Reaction with 2\% Ferric Chloride

AnthraquinonesBornträger reaction

Coumarins Reaction with 10\% Potassium Hydroxide in Ethanol

Tannins Reaction with 2\% Ferric Chloride

Anthocyanins and Reaction with Sulfuric Acid or Potassium Anthocyanidins Hydroxide

Flavones, Flavonois and Reaction with Magnesium and Xanthones Hydrochloric Acid

Chalcones and Auronas

Flavononols Reaction with Sulfuric Acid or Potassium

Leukoanthocyanidins Reaction with Hydrochloric Acid or Sodium Hydroxide

Catechins Reaction with Hydrochloric Acid or Sodium Hydroxide

Saponins Reaction with Hydrochloric Acid

$(+)$

Alkaloids Dragendoff Reaction, Mayer Reaction and Bouchardat/Wagner Reaction

(+) Positive (-) Negative

In this test, the presence of phenolic compounds, tannins and saponins was identified in the raw material (Endopleura uchi husks), where each one of these was identified from a chemical reaction. In the HEEu, the presence of phenolic compounds, tannins, anthocyanins and anthocyanidins, leucoanthocyanidins and saponins was observed. 
The metabolites found in the raw material (Endopleura uchi husks) and in HEEu have biological activities already reported in the literature, and phenolic compounds have natural antioxidant actions due to their chemical structure (RAMALHO; JORGE, 2006). Tannins are divided into two classes (hydrolyzable tannins and condensed tannins) where they have antibacterial activity (CASTEJON, 2011). Saponins have detergent and surfactant activities and their biological effect stands out for its antioxidant action, in addition to acting against tumor cells (PEREIRA; CARDOSO, 2012). In addition to these compounds, in HEEu were found anthocyanins, anthocyanidins and leucoanthocyanidins, which are compounds belonging to the flavonoid class, thus performing several biological effects, such as antioxidant, anti-inflammatory, antitumor and inhibition of collagen damage activity (PEREIRA; CARDOSO, 2012). Thus, the metabolites present in HEEu may be exerting pharmacological actions as observed from the results obtained in the in vivo analyzes in the present study.

The paw edema test induced by intraplantar carrageenan injection aims to trigger an inflammatory process, monitoring an increase in the volume of edema within a period of 4 hours after carrageenan application as shown in Figure 1.

FIGURE 1. Effects of Vehicle (V; $5 \%$ solution of $70 \%$ alcohol in saline solution; $10 \mathrm{ml} / \mathrm{kg}$; po), Indomethacin (Indo; $10 \mathrm{mg} / \mathrm{kg} ;$ po) and HEEu $(100 \mathrm{mg} / \mathrm{kg}$ and $300 \mathrm{mg} / \mathrm{kg}$; po) in paw edema induced by intraplantar carrageenan injection (Cg; 300 $\mu \mathrm{g} / \mathrm{paw}$ ). The animals were submitted to a basal reading (time 0 ) and thus pretreated. One hour after the pre-treatments, carrageenan was administered and the volume of edema measured 1, 2, 3 and 4 hours after injection. Each column represents the mean with 4 to 6 mice. The results are represented with an average of around E.P.M.

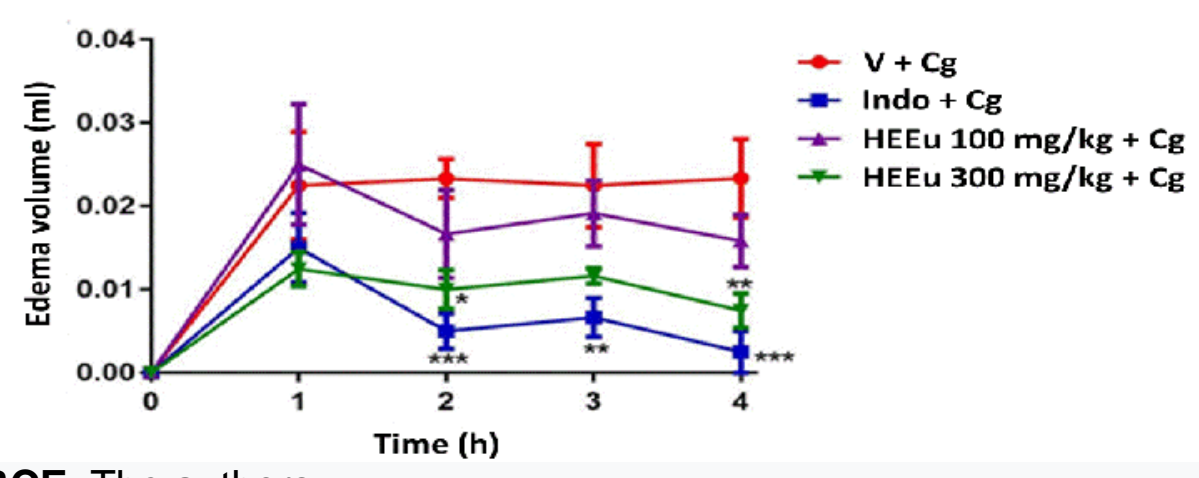

SOURCE: The authors

For the initial evaluation, the animals were submitted to a baseline reading of the paw volume (time 0) after which the animals were pretreated with Vehicle (5\% alcohol $70 \%$ solution in saline solution; $10 \mathrm{ml} / \mathrm{kg}$; po), Indomethacin $(10 \mathrm{mg} / \mathrm{kg} ; \mathrm{po})$ and HEEu (100mg/kg and $300 \mathrm{mg} / \mathrm{kg} \mathrm{po})$. Carrageenan $(300 \mu \mathrm{g} / \mathrm{paw})$ was then administered intraplantarly.

The swelling started to become evident one hour after applying Carrageenan and progressively increased during the remaining hours. HEEu at a dose of $300 \mathrm{mg} / \mathrm{kg}$ showed a reduction in edema in the $2 \mathrm{nd}$ hour $(p<0.05)$ when compared to the Vehicle group, in the 4th hour this reduction was more evident $(p<0.01)$ when compared to the Vehicle group. On the other hand, the HEEu at a dose of $100 \mathrm{mg} / \mathrm{kg}$ 
did not show any statistical difference when compared to the group treated with Vehicle. The Indomethacin group reduced edema from the 2 nd hour $(p<0.001)$ onwards, thus following it during the $3 r d(p<0.01)$ and 4 th $(p<0.001)$ hours compared to the Vehicle control group.

The carrageenan-induced paw edema test is a model widely used in studies to assess anti-inflammatory activity (FEZAI et al., 2013; TREVISAN et al., 2014). The experimental model uses carrageenan as an inflammation promoter where it promotes the formation of edema and its effects are related to the release of inflammatory mediators that increase vascular permeability and leukocyte migration (HUANG et al., 2011). Carrageenan triggers stimuli in two different phases where in its first phase (1-2 hours after carrageenan administration) there is an increase in vascular permeability resulting from the release of histamine and serotonin from mast cells (MALING et al., 1974; SILVA et al., 2017). The second phase of the response (3-4 hours after the carrageenan administration) is characterized by an inflammatory infiltrate, with release of bradykinin, $\mathrm{PGE}_{2}$, cytokines, which can be cited as examples interleukin-1 beta (IL-1 $\beta$ ), factor of tumor necrosis -alpha (TNF- $\alpha$ ), interleukin-10 (IL10) and nitric oxide (MEDZHITOV, 2008; SILVA et al., 2017).

Bergenin is a metabolite isolated from the bark of the species Endopleura uchi where in studies to assess the anti-inflammatory activity in vitro it was shown that it has inhibitory activity for cyclooxygenase-2 (COX-2), the main isoform of COX induced during inflammation, and the induction of COX-2 is responsible for the production of PGs at the site of inflammation (NUNOMURA, 2009). Thus, the present research demonstrated that the administration of HEEu promoted the reduction of edema from the second hour of the test, suggesting that the metabolite bergenin may be exerting this effect.

The $0.9 \%$ acetic acid-induced abdominal writhing test evaluated the number of abdominal writhings during 20 minutes after administration of Vehicle (V; $5 \%$ solution of $70 \%$ alcohol in saline solution; $10 \mathrm{ml} / \mathrm{kg} ; \mathrm{po}$ ), Indomethacin (INDO; $10 \mathrm{mg} / \mathrm{kg} ; \mathrm{po}$ ), $\mathrm{HEEu}(100 \mathrm{mg} / \mathrm{kg}$ and $300 \mathrm{mg} / \mathrm{kg}$; po). Figure 2 shows that animals treated with Indomethacin showed a reduction $(p<0.01)$ in the number of writhes compared to the control group Vehicle. The HEEu at dosages of 100 and $300 \mathrm{mg} / \mathrm{kg}$ showed a reduction $(p<0.05)$ when compared to Vehicle.

FIGURE 2. Effects of Vehicle ( $\mathrm{V} ; 5 \%$ solution of $70 \%$ alcohol in saline solution; $10 \mathrm{ml} / \mathrm{kg} ; \mathrm{po}$ ), Indomethacin (INDO; $10 \mathrm{mg} / \mathrm{kg} ;$ po) and HEEu $(100 \mathrm{mg} / \mathrm{kg}$ and $300 \mathrm{mg} / \mathrm{kg}$; vo) in the number of abdominal contortions induced by $0.9 \%$ acetic acid $(\mathrm{v} / \mathrm{v})$ for 20 minutes. Each column represents an average of 4 to 6 mice. The results are represented with an average of plus or minus the E.P.M.

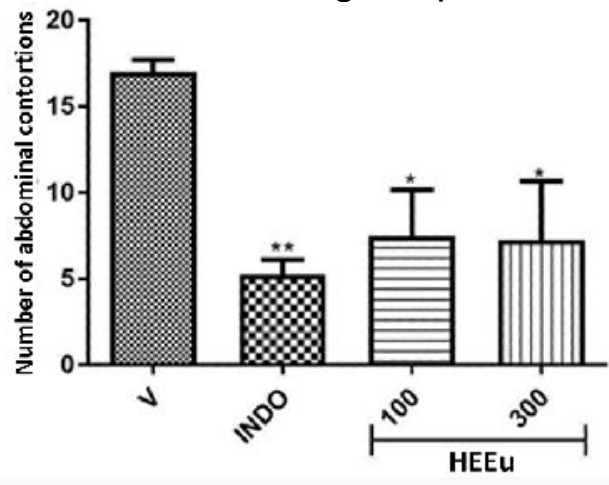

SOURCE: The authors. 
Acetic acid-induced abdominal writhing testing has been used as a screening tool to assess the analgesic properties of new substances (COLLIER et al., 1968). Previous studies postulated that acetic acid acts indirectly by inducing the release of endogenous mediators that stimulate nociceptive neurons which are sensitive to nonsteroidal anti-inflammatory drugs (NSAIDs) and opioids (FISCHER et al., 2008). The mediators released from acetic acid are cyclooxygenase (COX), lipoxygenase (LOX), prostaglandins (PGs), histamine, serotonin, bradykinin, substance P, IL-1 interleukin-8 (IL-8), TNF- $\alpha$ na peritoneal cavity (FARIAS et al., 2011). HEEu reduced acetic acid-induced writhing in mice. The results support the hypothesis that the extract has an antinociceptive effect on abdominal contortions, thus suggesting a characteristic of the class of non-steroidal anti-inflammatory drugs where they will act in reducing the synthesis of prostaglandin mediators, promoting an antinociceptive action.

The Rota Rod test aimed to evaluate the motor performance of the animals in the times of 30,60, 120 minutes after the treatments. Time 0 shown in Figure 3 is the baseline reading, i.e., without animals with pharmacological treatment. After time 0 , Xylazine (2mg/kg; via s.c.), Vehicle (10ml/kg; v.o.) and HEEu (300mg/kg; v.o.) were administered. From this on, at times of 30,60 and 120 minutes, it was evaluated whether the HEEu exerts action on motor activity, either by sedation or by muscle relaxation. The animals treated with HEEu $(300 \mathrm{mg} / \mathrm{kg})$ did not show changes in their motor performance in any of the times at 30,60 and 120 when compared to the control group that received the vehicle. Unlike the control treated with Xylazine, which demonstrated a significant reduction in the time spent on the rotating bar at 30 and 60 minutes $(p<0.05)$ compared to the control treated with the Vehicle group (Figure 3).

FIGURE 3. Effects of Vehicle ( $\mathrm{V} ; 5 \%$ solution of $70 \%$ alcohol in saline solution; $10 \mathrm{ml} / \mathrm{kg}$; po), Xylazine (2mg/kg; via sc) and HEEu (300mg/kg) on the time spent on the bar swivel on the rota-rod test. The time was measured from their administration after the basal reading (time 0 , when the animals did not receive any type of treatment) and measured at 30,60 and 120 minutes after administration. Each column represents the mean with 4 to 6 mice per group. The results are represented with an average of around E.P.M.

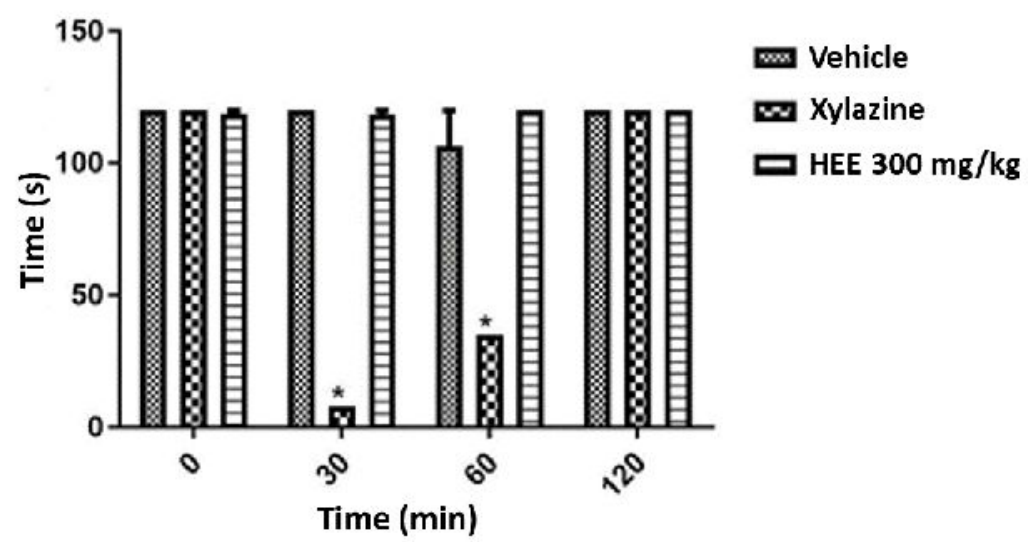

SOURCE: The authors 
For this conclusion, the Rota-rod test was used to assess the specificity of the antinociceptive action of drugs, checking whether they cause motor incoordination, whether by sedation and/or muscle relaxation (ROSLAND et al., 1990). No interference was observed in the motor coordination of animals in the rota-rod test, thus eliminating a muscle relaxation or sedative effect of HEEu. This demonstrates that the action of HEEu does not cause sedation or a relaxing effect, acting directly on nociception.

\section{CONCLUSION}

In conclusion, this study indicates that the hydroethanolic extract of the bark of the Endopleura uchi species exhibited anti-inflammatory and antinociceptive activities. The results found support previous claims of its traditional use. It is suggested that the mechanism of action of HEEu is associated with the inhibition of the formation of pro-inflammatory mediators, such as NSAIDs. In addition, we demonstrate that the extract of $E$. uchi presented in the phytochemical prospection compounds that can exert these activities found as well as the antioxidant activity observed in the tests.

\section{REFERENCES}

AKERELE, O. 1993. Summary of WHO guidelines for assessment of herbal medicines. Herbal Gram, v.28, p.13-19.

AMOROZO, M.C.M., GÉLY, A.L. 1998. Use of medicinal plants by caboclos from the lower Amazon, Barcarena, PA, Brazil. Boletim do Museu Paraense Emílio Goeldi, Série Botânica, v.4, n.1, p.47-131. Portuguese.

BADKE, M. R., SOMAVILLA, C. A., HEISLER, E. V., DE ANDRADE, A., BUDÓ, M. D. L. D. et al. 2016. Popular knowledge: use of medicinal plants as a therapeutic form in health care. Revista de Enfermagem da UFSM, 6(2), 225-234.

BRASIL. Ministério da Saúde. A fitoterapia no SUS e o programa de Pesquisas de Plantas Medicinais da Central de Medicamentos. Brasília (DF): MS; 2006

BORGES, J. C., RIPARDO FILHO, H. D. S., GUILHON, G. M. S. P., CARVALHO, J. C., SANTOS, L. S. et al. 2011. Antinociceptive activity of acetylbergenin in mice. Lat. American Journal of Pharmacheutical educacion , 30(7), 1303-8.

CASTEJON, F. V. Taninos e saponinas. Seminário apresentado junto à disciplina Seminários Aplicados do Programa de Pós-graduação-Universidade Federal de Goiás, Goiânia, 2011.

CHANG, C. C., YANG, M. H., WEN, H. M., CHERN, J. C. 2002. Estimation of total flavonoid content in propolis by two complementary colorimetric methods. Journal of food and drug analysis, 10(3).

COLLIER, H.O., DINNEEN, L.C., JOHNSON, C.A., SCHNEIDER, C., 1968. Abdominal contrition response and its suppression by analgesic drugs in mouse. 
British Journal of Pharmacology and Chemotherapy, vol. 32, no. 2, pp. 295-310. DOI: 10.1111/j.1476-5381.1968.tb00973.x.

COSTA, A. F. 2001. Farmacognosia experimental. Lisboa: Fundação Calouste.

CUATRECASAS, J. 1961. A taxonomic revision of the Humiriaceae. Systematic Plant Studies.

FARIAS, J.A.C., FERRO, J.N.S., SILVA, J.P., AGRA, I.K.R., OLIVEIRA, F.M. et al. 2012. Modulation of inflammatory processes by leaves extract from Clusia nemorosa both in vitro and in vivo animal models. Inflammation, 35(2), 764-771. DOI: $10.1007 / \mathrm{s} 10753-011-9372-y$

FEZAI, M., SENOVILLA, L., JEMAÀ, M., BEN-ATTIA, M. 2013. Analgesic, antiinflammatory and anticancer activities of extra virgin olive oil. Journal of lipids, 2013. Disponível em: https://doi.org/10.1155/2013/129736

FISCHMAN, L. A., SKORUPA, L. A., SOUCCAR, C., LAPA, A. J. 1991. The water extract of Coleus barbatus Benth decreases gastric secretion in rats. Memórias do Instituto Oswaldo Cruz, 86, 141-143.

HUANG, G. J., DENG, J. S., HUANG, S. S., CHANG, C. I., CHANG, T. N. et al. 2011. Anti-inflammatory activities of $6 \beta$-acetoxy- $7 \alpha$-hydroxyroyleanone from Taiwania cryptomerioides Hayata ex vivo and in vivo. Journal of Agricultural and Food Chemistry, 59(20), 11211-11218. Dipsonível em: https://doi.org/10.1021/jf200576f.

LEVY, L. 1969. Carrageenan paw edema in the mouse. Life Sciences, 8(11), 601606. Disponível em: https://doi.org/10.1016/0024-3205(69)90021-6.

LUNA, J. S., SILVA, T. M., BENTO, E. S., SANTANA, A. E. G. 2000. Isolation and structural identification of the chemical constituents of Endopleura uchi (Humiriaceae). Reunião Anual da Sociedade Brasileira de Química, Minas Gerais, Brasil, 2, 123.

KOSTER, R.; Acetic acid for analgesic screening. Federation Proceedings, 18, 412-417.1959.

KUSKOSKI, E. M., ASUERO, A. G., GARCíA-PARILLA, M. C., TRONCOSO, A. M., FETT, R. 2004. Actividad antioxidante de pigmentos antociánicos. Food Science and Technology, 24(4), 691-693. Disponível em: https://doi.org/10.1590/S010120612004000400036.

MAGALHÃES, L. A. M., LIMA, M. D. P., MARINHO, H. A., FERREIRA, A. G. 2007. Identification of bergenin and carotenoids in the uchi (Endopleura uchi, Humiriaceae) fruit. Acta Amazonica, 37(3), 447-450. Disponível em: https://doi.org/10.1590/S0044-59672007000300016. 
MALING, H. M., WEBSTER, M. E., WILLIAMS, M. A., SAUL, W., ANDERSON, W. 1974. Inflammation induced by histamine, serotonin, bradykinin and compound $48 / 80$ in the rat: antagonists and mechanisms of action. Journal of Pharmacology and Experimental Therapeutics, 191(2), 300-310.

MEDZHITOV, R. 2008. Origin and physiological roles of inflammation. Nature, 454 (7203), 428-435.

MENSOR, L. L., MENEZES, F. S., LEITÃO, G. G., REIS, A. S., SANTOS, T. C. D. (2001). Screening of Brazilian plant extracts for antioxidant activity by the use of DPPH free radical method. Phytotherapy research, 15 (2), 127-130. DOI: $10.1002 / p t r .687$.

MONOBE, M., EMA, K., KATO, F., MAEDA-YAMAMOTO, M. 2008. Immunostimulating activity of a crude polysaccharide derived from green tea (Camellia sinensis) extract. Journal of Agricultural and Food Chemistry, 56(4), 1423-1427. DOI: 10.1021/jf073127h.

MUNIZ, M. P., NUNOMURA, S. M., LIMA, E. S., LIMA, A. S., ALMEIDA, P. et al. 2020. Quantification of bergenin, antioxidant activity and nitric oxide inhibition from bark, leaf and twig of Endopleura uchi. Química Nova, 43(4), 413-418. Disponível em: https://doi.org/10.21577/0100-4042.20170514

NACZK, M., SHAHIDI, F. 2004. Extraction and analysis of phenolics in food. Journal of Chromatography A, 1054(1-2), 95-111.

NUNOMURA, R., OLIVEIRA, V. G., DA SILVA, S. L., NUNOMURA, S. M. 2009. Characterization of bergenin in Endopleura uchi bark and its anti-inflammatory activity. Journal of the Brazilian Chemical Society, 20(6), 1060-1064. Disponível em: https://doi.org/10.1590/S0103-50532009000600009

OLIVEIRA, G.R.B.; Avaliação da eficácia antilipidêmica da Endopleura uchi Huber Cuatrec pelo método de inibição da lipase pancreática. 2014. Dissertação (Mestrado em Ciências Farmacêuticas) - Universidade Federal de Juiz de Fora

PEREIRA, R. J., CARDOSO, M.G.; Metabólitos secundários vegetais e benefícios antioxidantes. Journal of Biotechnology and Biodiversity, 3(4).2012.

POLITI, F. A., MELLO, J. C., MIGLIATO, K. F., NEPOMUCENO, A. L., MOREIRA, R. R. Antimicrobial, cytotoxic and antioxidant activities and determination of the total tannin content of bark extracts Endopleura uchi. International Journal of Molecular Sciences, 12(4), 2757-2768, 2011.

POLITI, F. A. S., MOREIRA, R. R. D., SALGADO, H. R. N., PIETRO, R. C. L. R. 2010. Preliminary tests on acute oral toxicity and intestinal motility with extract of pulverized bark of Endopleura uchi (Huber) Cuatrec. (Humiriaceae) in mice. PanAmazônica Saúde, 1, 187-189. Disponível em: http://dx.doi.org/10.5123/S217662232010000100026 . 
RAMALHO, V. C., JORGE, N.; Antioxidants used in oils, fats and fatty foods. Química nova, 755-760.2006. Disponível em: https://doi.org/10.1590/S010040422006000400023.

RE, R., PEllegrini, N., PROtegGente, A., PANNALA, A., YANG, M. et al. Antioxidant activity applying an improved ABTS radical cation decolorization assay. Free Radical Biology and Medicine, 26(9-10), 1231-1237.1999. DOI: 10.1016/s0891-5849(98)00315-3.

ROSLAND, J. H., HUNSKAAR, S., HOLE, K.;Diazepam attenuates morphine antinociception testdependently in mice. Pharmacology \& Toxicology, 66(5), 382-386, 1990. Disponível em: https://doi.org/10.1111/j.1600-0773.1990.tb00766.x

SMITH, N., MORI, S. A., HENDERSON, A., STEVENSON, D. W., HEALD, S. V. 2004. Flowering Plants of the Neotropics. Princeton University Press.

SEYFRIED, M., SOLDERA-SILVA, A., BOVO, F., STEVAN-HANCKE, F. R., MAURER, J. B. B. et al. Pectinas de plantas medicinais: características estruturais e atividades imunomoduladoras. Revista Brasileira de Plantas Medicinais, 18(1), 201-214.2016. Disponível em: https://doi.org/10.1590/1983-084X/15_078

SILVA, S. L. D., OLIVEIRA, V. G. D., YANO, T., NUNOMURA, R. D. C. S. Antimicrobial activity of bergenin from Endopleura uchi (Huber) Cuatrec. Acta amazônica, 39(1), 187-191.2009. Disponível em: https://doi.org/10.1590/S004459672009000100019.

SILVA I.S., NICOLAU L.A., SOUSA F.B., DE ARAÚJO S., OLIVEIRA A.P., ARAÚJO T.S., SOUZA L.K.M., MARTINS C.S., AQUINO P.E.A., CARVALHO L.L., et al. Evaluation of anti-inflammatory potential of aqueous extract and polysaccharide fraction of Thuja occidentalis Linn. in mice. International Journal of Biological Macromolecules, 105, 1105-1116.2017. DOI: 10.1016/j.jjbiomac.2017.07.142.

SIMÕES, C. M. O. 2001. Farmacognosia: da planta ao medicamento. UFRGS; Florianópolis: UFSC.

TREVISAN G., ROSSATO M.F., HOFFMEISTER C., MULLER L.G., PASE C. et al. Antinociceptive and antiedematogenic effect of pecan (Carya illinoensis) nut shell extract in mice: a possible beneficial use for a by-product of the nut industry. Journal of Basic and Clinical Physiology and Pharmacology, 25(4), 401-410.2014. DOI: 10.1515/jbcpp-2013-0137.

TOMAZZONI M.I., NEGRELLE R.R.B., CENTA M.L. Popular herbal medicine: the institutional search as a therapeutic practice.2006. Texto \& Contexto Enfermagem;15(1):115-2.

VEIGA JUNIOR, V. F., PINTO, A. C., MACIEL, M. A. M.; Medicinal plants: safe cure. Química nova, 28(3), 519-528.2005. 